\title{
A review of the genus Paramoniezia Maplestone et Southwell, 1923 (Cestoda: Anoplocephalidae), with a new genus, Phascolocestus, from wombats (Marsupialia) and redescriptions of Moniezia mettami Baylis, 1934 and Moniezia phacochoeri (Baylis, 1927) comb. n. from African warthogs (Artiodactyla)
}

\author{
Ian Beveridge
}

Department of Veterinary Science, University of Melbourne, Veterinary Clinical Centre, Werribee, Victoria, Australia

\begin{abstract}
Paramoniezia suis Maplestone et Southwell, 1923 is redescribed from the type and only specimen, and is considered to be a genus inquirendum and species inquirenda, possibly based on a host misidentification. Paramoniezia phacochoeri Baylis, 1927 is redescribed from new material from Phacochoerus africanus (Gmelin) from South Africa and is transferred to Moniezia Blanchard, 1891 as M. phacochoeri (Baylis, 1927) comb. n. A redescription of M. mettami Baylis, 1934, also from Ph. africanus, establishes the independence of the two congeneric species parasitizing warthogs. A new genus, Phascolocestus, is erected for Paramoniezia johnstoni Beveridge, 1976 from vombatid marsupials as Phascolocestus johnstoni (Beveridge, 1976) comb. n., and additional host and distributional data are provided for this species.
\end{abstract}

Keywords: taxonomy, Paramoniezia suis, new genus, Australia, Africa

Paramoniezia Maplestone et Southwell, 1923 was erected based on a superficial description of a single cestode purportedly collected from a wild pig, Sus scrofa, in Queensland, Australia (Maplestone and Southwell 1923). The inadequacy of the original description, the poor state of preservation of the holotype and only specimen, and the fact that no cestodes have ever since been found in pigs in Australia (Mackerras 1958) has in part contributed to its extremely confusing taxonomic history (Spasskii 1951).

The genus was subsequently used to accommodate a number of species from unrelated hosts, including P. phacochoeri Baylis, 1927 from the warthog, previously known as Phacochoeurus aethiopicus (Pallas), in Africa, but which is specifically distinct from $P h$. africanus (Gmelin), now considered to be the correct host name for the cestode, P. psittacea (Fuhmann, 1904) from a parrot, Strigops habroptilus Gray, from New Zealand, and P. johnstoni Beveridge, 1976 from marsupials, wombats Vombatus ursinus (Shaw) and Lasiorhinus latifrons (Owen), in Australia, hence leading to a highly unlikely host distribution.

Some, but not all of the dubious allocations to this genus have been resolved previously, such as that of P. psittacea. Baer (1927) considered this cestode, originally described as Cittotaenia psittacea Fuhrmann, 1904, from a New Zealand flightless parrot, the kakapo, Strigops habroptilus Gray, to be the same species as P. suis and reduced Paramoniezia to a synonym of Cittotaenia Rheim, 1881.

Baylis (1927) attributed a second species to Paramoniezia, P. phacochoeri from warthogs (Phacochoerus aethipiocus, now considered to be $P$. africanus) in Uganda, even though the specimens at his disposal were immature and no features of the uterus were observable, a key feature in the generic allocation of anoplocephalid cestodes (Beveridge 1994). The unlikely nature of the synonymy proposed by Baer (1927) led Spasskii (1951) to re-establish the genus Paramoniezia with three species, $P$. suis (type species), P. psittacea and P. phacochoeri.

The key differentiating feature of the genus identified in the original description of $P$. suis by Maplestone and Southwell (1923) was that while in Cittotaenia, the vagina was ventral to the cirrus sac on both sides of the strobila, and in Moniezia Blanchard, 1891 it was ventral on the right and dorsal on the left, in $P$. suis, the vagina was considered to be variable in position on the left side of the strobila being either dorsal or ventral to the cirrus sac.

This differentiation of genera did not take into account differences in the tubular to slightly reticulate uterine structure of Cittotaenia (as constituted at that time) and the highly reticulate nature of the uterus in Moniezia. 
Spasskii (1951) redefined the genus Paramoniezia in part emphasizing the distribution of testes throughout the medulla, chiefly anterior to the uterus as an additional differentiating feature. As a consequence, this poorly defined genus has remained in the literature with Yamaguti (1959) admitting two species, $P$. suis and $P$. phacochoeri,

As part of a revision of the anoplocephalid cestodes of Australian marsupials, Beveridge (1976) re-examined the types of $P$. suis and concluded that is was difficult to confirm its key differentiating features, but used the re-definition of Spasskii (1951) to allocate a new species P. johnstoni Beveridge, 1976 from wombats to the genus rather than create a new monotypic genus. He speculated (Beveridge 1976) that the original specimen of $P$. suis may not have been from $S$. scrofa, but possibly from the northern hairy-nosed wombat, Lasiorhinus $\mathrm{kr}$ efftii (Owen) (then known as L. barnardi), which at the time of Maplestone's collecting activities was extant near Townsville in Queensland, Australia, and was referred to colloquially as a "bush pig".

Subsequently, Beveridge (1978) redescribed P. psittacea, removing it to a new genus Stringopotaenia Beveridge, 1978. As a consequence, Paramoniezia currently includes the type species, $P$. suis, as well as P. phacochoeri from warthogs and $P$. johnstoni from wombats. Schmidt (1986) treated Paramoniezia as a valid genus, admitting P. suis and P. johnstoni, although P. phacochoeri was not included in his monograph.

A recent molecular study of Australian anoplocephalids has suggested that the species found in wombats, P. johnstoni and Phascolotaenia comani Beveridge, 1976, form a distinct endemic clade (Hardman et al. 2012), casting increasing doubt on the current composition of the genus Paramoniezia. As a consequence, it was decided to review the genus, to examine any new material available and to re-examine in detail the type specimen of $P$. suis to see whether any additional morphological information could be obtained, which might have a bearing on the systematics of the genus, and to re-examine the types as well as additional material of $P$. phacochoeri and redescribe the species. As this species is remarkably similar to Moniezia mettami Baylis, 1934, also from warthogs in Africa, and the differentiation of these species in the available literature was not clear, a redescription of this species was also undertaken.

\section{MATERIALS AND METHODS}

All available material of Paramoniezia suis, $P$. phacochoeri and $P$. johnstoni as well as Moniezia mettami was examined. Abbreviations of institutions from which specimens were examined were as follows: The Natural History Museum, London (BMNH), Muséum d'Histoire naturelle, Geneva (MHNG), the Onderstepoort Institute of Veterinary Research, South Africa (OVRL) and the South Australian Museum, Adelaide (SAM). Unmounted specimens were stained in celestine blue, dehydrated in ethanol, cleared in methyl salicylate and mounted in bal- sam. Portions of strobilae were embedded in paraffin and serial sections were cut at a thickness of $5 \mu \mathrm{m}$; sections were stained with haematoxylin and eosin.

Drawings were made with the aid of a drawing tube attached to an Olympus BH microscope. In order to show the relative positions of internal organs such as the testes, seminal receptacle, ovary and vitellarium in whole mounts, dorsoventral relationships have been ignored in some instances in the illustrations. Measurements are present in $\mu \mathrm{m}$ unless otherwise indicated as the range followed by the mean and the number of measurements made in parentheses. Eggs were removed from gravid segments of new specimens and examined in water before clearing in lactophenol for measurements.

\section{RESULTS}

Family Anoplocephalidae Cholodkovsky, 1902

Genus Paramoniezia Maplestone et Southwell, 1923

Paramoniezia suis Maplestone et Southwell, 1923

Figs. 1-4

Redescription (based on holotype). Robust, severely contracted worm, $9 \mathrm{~mm}$ wide. Longitudinal musculature composed of prominent bundles of fibres surrounding medulla; transverse muscle fibres prominent at lateral margins of segment; few dorsoventral fibres present.

Ventral osmoregulatory canals large, $c a 255$ in diameter, connected at posterior end of segment by transverse canal ca 46 in diameter; dorsal osmoregulatory canal slender, ca 40 in diameter, joined at posterior end of segment by slender transverse canal c. 15 in diameter. Scolex 460 in diameter, unarmed with four suckers $c a 190$ in diameter. Neck absent. Mature segments craspedote, 154 long, greatly extended transversely; length width ratio $1: 58$.

Genitalia paired; genital atrium opens in middle of lateral margin of segment. Cirrus sac small, pyriform, 230-340 (277, $\mathrm{n}=5)$ long, 77-108 (92, n = 5) wide, barely reaching half way to osmoregulatory canals. Cirrus with thick wall, unarmed, leading to internal seminal vesicle varying in size; prior to filling. Internal seminal vesicle diminutive, $c$. $116 \times 40$, expanding when filled to occupy most of cirrus sac, measuring up to $246 \times 108$. External seminal vesicle prominent, coiled, wall thick but without glandular investment. Vas deferens narrow, running dorsal to osmoregulatory canals. Testes extending in single band across medulla between osmoregulatory canals, reaching osmoregulatory canals on both sides of segment; reduced to single band anterior to ovary and seminal receptacle, 1-3 transverse rows present in middle of segment; testes mainly in posterior half of medulla, except for those anterior to seminal receptacles; testis number c. 215 (based on counting testes in illustration); testis diameter 30-70 $(46, \mathrm{n}=10)$.

Ovary flabelliform, ovarian isthmus medial to seminal receptacle, ovary 423-640 $(540, \mathrm{n}=5)$ long, 92-116 (108, $\mathrm{n}=5$ ) wide. Vagina opens to genital atrium posteriorly to cirrus sac; of 24 transverse sections examined through dif- 
1

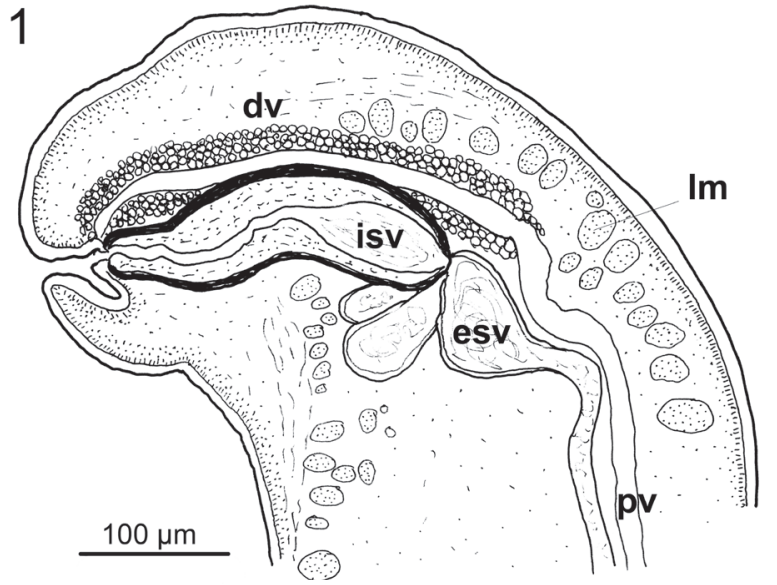

3

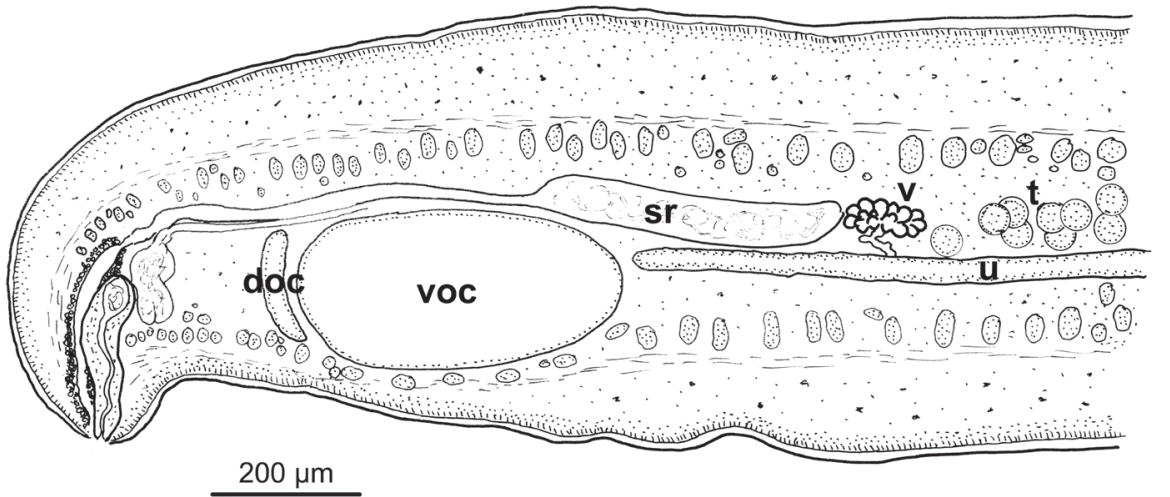

4
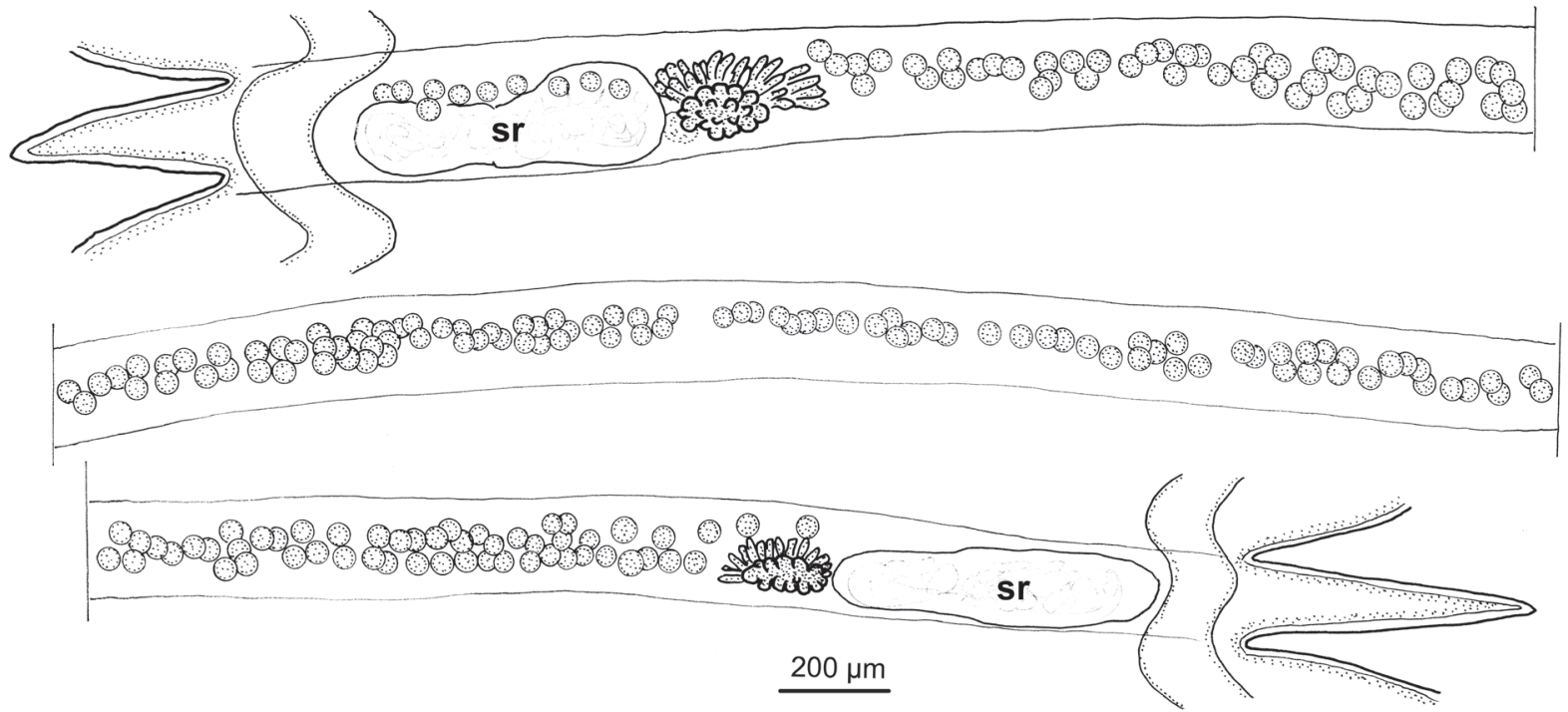

Figs. 1-4. Paramoniezia suis Maplestone et Southwell, 1923 from Sus scrofa, Queensland, Australia. Illustrations of holotype. Fig. 1. Transverse section of terminal genitalia. Fig. 2. Egg. Fig. 3. Transverse section of mature segment, showing relationships of the genital ducts to the osmoregulatory canals. Fig. 4. Mature segment, divided into three sections. Abbreviations: doc - dorsal osmoregulatory canal; $\mathrm{dv}$ - distal vagina; esv - external seminal vesicle; isv - internal seminal vesicle; $1 \mathrm{~m}$ - longitudinal musculature; pv - proximal vagina; $\mathrm{sr}$ - seminal receptacle; $\mathrm{t}$ - testis; $\mathrm{u}$ - uterus; $\mathrm{v}$ - vitellarium; voc - ventral osmoregulatory canal.

ferent genital atria, on right hand side, cirrus sac ventral to vagina in 12 , dorsal in 3 ; on left hand side, cirrus sac ventral to vagina in 5 , dorsal in 4 . Distal region of vagina 246-308 $(285, \mathrm{n}=5)$ long, with thick wall, surrounded by mass of deeply staining glandular cells, vagina 39-69 (54, $\mathrm{n}=5$ ) in diameter. Proximal vagina slender, tubular, lacking glandular investment, $15(\mathrm{n}=5)$ in diameter, running with vas deferens dorsal to osmoregulatory canals. Semi- 
nal receptacle large, ovoid, in some cases almost bilobed, 540-815 (690, $\mathrm{n}=5$ ) long, 130-230 (162) wide.

Vitellarium medial to seminal receptacle, posterior to ovary, 85-100 (92, $\mathrm{n}=5)$ long, 108-177 (139, $\mathrm{n}=5)$ wide; Mehlis' gland between vitellarium and seminal receptacle, $77-100(85, \mathrm{n}=5)$ in diameter. Uterus single, transverse, tubular, reaching osmoregulatory canals; in mature segments, most testes anterior to uterus, some posterior to it.

Eggs spherical, 48-52 (50, $\mathrm{n}=5)$ in diameter; pyriform apparatus conical without reflexed filaments, 25-31 $(27, \mathrm{n}=5)$ long; oncosphere $17-19(18, \mathrm{n}=5)$ in diameter.

Type host: Sus scrofa (Linnaeus) (Suidae), feral pig.

Type locality: Townsville, Queensland, Australia.

Site of infection: Small intestine.

Material examined: Types of Paramoniezia suis, one slide of four hand-cut longitudinal sections, three slides with serial longitudinal sections, four slides with serial transverse sections, three slides with hand-cut transverse sections, one slide with hand-cut sagittal sections (BMNH 1977.11.1.29); spirit specimen (fragments) (BMNH 1977.10.25.30); 18 slides with serial sagittal sections of near gravid segment (MHNG - PLAT 37278, C123/82-100).

Remarks. Although extremely poorly preserved, it was possible to obtain additional information from the type specimens of $P$. suis. Beveridge (1976) indicated that Maplestone and Southwell (1923) had not described the osmoregulatory system accurately and that a standard system of paired dorsal and ventral longitudinal ducts was present with connections at the posterior margin of each segment, rather than a 'branched' system and the lack of a dorsal vessel described originally. These observations were confirmed in the present redescription.

Since the original differentiation of the genus was based primarily on the relative positions of the vagina and cirrus sac on the left and right hand sides of the strobila, this situation was examined carefully and all transverse sections in which these features were clearly observable were documented. In a total of 24 such transverse sections of different sets of genitalia, the vagina and cirrus sac were either dorsal or ventral to one another on either side of the strobila, thereby invalidating the original criterion upon which the genus was based.

In spite of this finding, there were several features, described for the first time, which potentially define the genus. The cirrus sac did not reach the osmoregulatory canals and the vagina was divided into a distal region, which was surrounded by a mass of gland cells followed by a narrow duct without gland cells leading to an enormous elongate seminal vesicle. The only anoplocephalid genus with similar features is Wallabicestus Schmidt, 1986 from Australasian macropodid marsupials (see Beveridge 2009, Hardman et al. 2012).

Beveridge $(1976,1978)$ placed emphasis on the distribution of testes either anterior or posterior to the uterus in defining anoplocephaline genera with tubular uteri.
This differentiation is least effective in the case of species of Wallabicestus (then Progamotaenia ewersi Schmidt, 1975), in which testes may be present anterior to the uterus in immature segments, but are later mainly posterior to the uterus (Beveridge 2009). In P. suis, determining the distribution of testes was complicated by the extraordinary lateral extension of the segments due to severe contraction of the specimen.

In spite of the extreme lateral extension of the segments, most testes appear to be in the posterior half of the segment, except in the lateral regions where they occur anterior to the ovary and seminal receptacle. In this respect, their distribution resembles that found in $\mathrm{Ph}$. comani from Australian wombats (Beveridge 1976). It was extremely difficult to trace the position of the immature uterus in the specimen available, but it appeared to run between testes, although mainly posterior to them and closer to the posterior margin of the segment. Because of this, it is difficult to use it as a differentiating feature.

Overall, in terms of the morphology of the vagina and the seminal receptacle as well as the distribution of the testes, P. suis appears to be closest to species of $\mathrm{Wal}$ labicestus found in macropodid marsupials. It differs in the extreme lateral elongation of the segments and in the morphology of the cirrus sac, which is more elongate in $P$. suis, but which is subglobular and has numerous gland cells surrounding the cirrus in Wallabicestus but not in $P$. suis. The shape of the pyriform apparatus, which is conical in P. suis, but is branched in species of Moniezia, is also similar to species of Wallabicestus. In the case of P. johnstoni, the pyriform apparatus has four branches (Beveridge 1976).

Based on these differences, Paramoniezia is retained as a genus, with a single species, $P$. suis, but with the recognition that it is closely related to Wallabicestus and that it is most likely that the true host was a macropodid marsupial rather than a pig. P.A. Maplestone was acting director of the Institute for Tropical Medicine in Townsville, Queensland, Australia, in 1921 and collected a number of nematode parasites from agile wallabies, Macropus agilis (Gould), which he subsequently described with Prof. W. Yorke in Liverpool in 1926 (Yorke and Maplestone 1926, Beveridge 1998). Not only the microscopic features but also the gross features of the remaining fragments of $P$. suis bear a strong similarity to $W$. ewersi, which is a common cestode parasite of $M$. agilis in the Townsville region (Speare et al. 1983). It is most likely that $P$. suis is a mislabelled specimen of $W$. ewersi, but there is insufficient evidence to synonymise the two taxa, much of the evidence presented here being circumstantial.

Moniezia phacochoeri (Baylis, 1927) comb. n.

Figs. 5-12, 21, 23

Syn.: Paramoniezia phacochoeri Baylis, 1927

Redescription (Based on seven specimens from OVRL): Large cestodes, 23-31 (27, $\mathrm{n}=5) \mathrm{cm}$ long, 


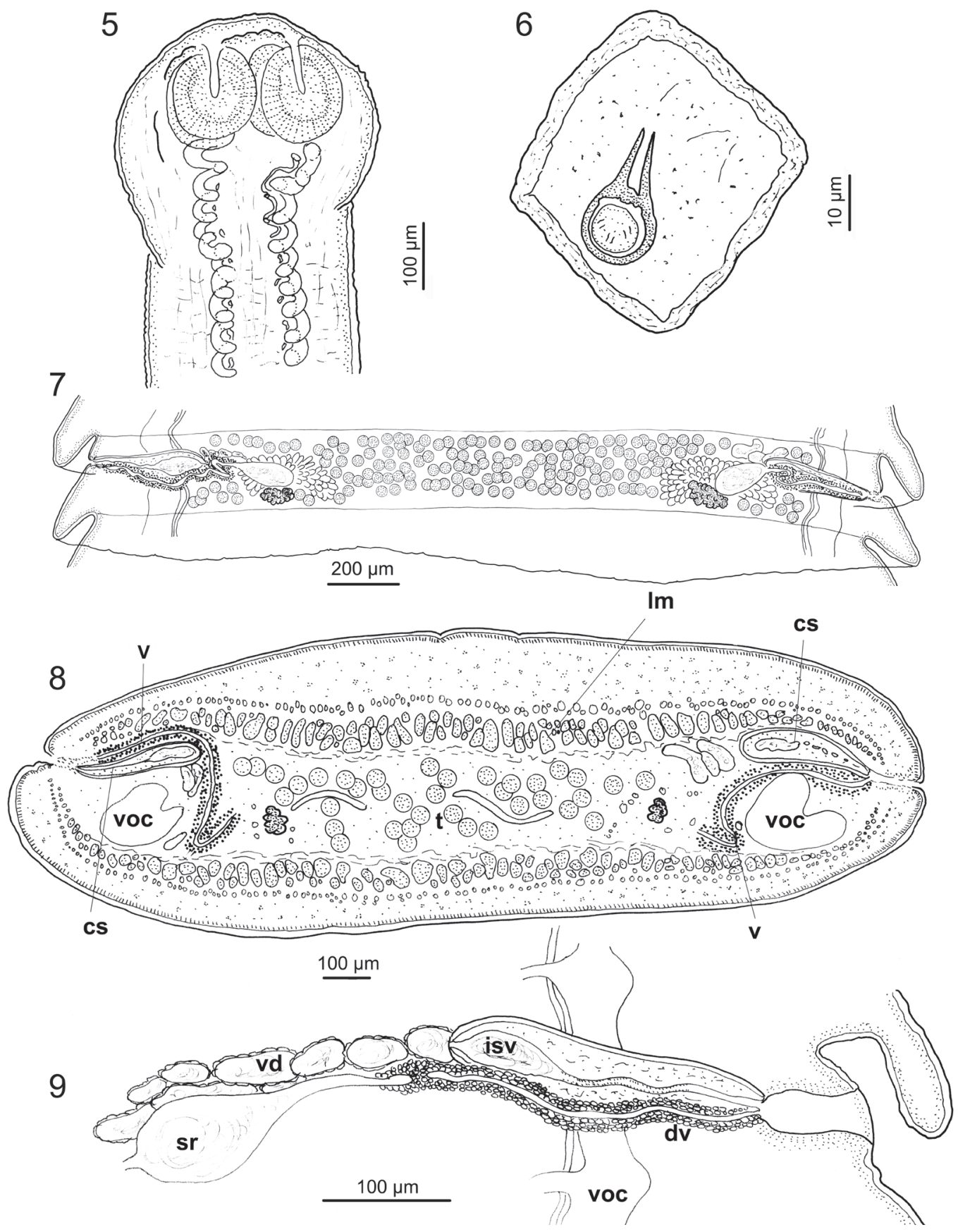

Figs. 5-9. Moniezia phacochoeri (Baylis, 1927) comb. n. Specimens from Phacochoerus africanus from South Africa. Fig. 5. Scolex. Fig. 6. Egg. Fig. 7. Mature segment. Fig. 8. Transverse section of mature segment. Fig. 9. Distal genital ducts, showing cirrus sac extending beyond osmoregulatory canals and cellular investment of distal vagina. Abbreviations: cs - cirrus sac; dv - distal vagina; isv - internal seminal vesicle; $\mathrm{lm}$ - longitudinal musculature; $\mathrm{sr}$ - seminal receptacle; $\mathrm{t}$ - testis; $\mathrm{v}$ - vagina; vd - vas deferens; voc - ventral osmoregulatory canal.

maximum width $0.9-1.3(1.05, \mathrm{n}=5) \mathrm{cm}$, with hundreds of segments. Longitudinal musculature well developed, composed of two layers of muscle bundles; outer layer much smaller than inner layer; transverse muscle fibres form narrow band immediately internal to longitudinal muscles; dorsoventral muscle fibres few, scattered.

Osmoregulatory canals paired; ventral canal larger, 120-230 $(160, \mathrm{n}=5)$ in diameter, external to smaller dor- sal canal, $10-20(16, n=5)$ in diameter; transverse canal connects ventral canals at posterior margin to each segment; no transverse dorsal canal seen. Some additional tiny dorsal canals visible in transverse sections but not visible in whole mounts.

Scolex 450-690 $(610, \mathrm{n}=5)$ in diameter, unarmed, with four suckers $200-240(220, n=5)$ in diameter; neck 300-1050 (800, $\mathrm{n}=5)$ (specimens slightly contracted). 


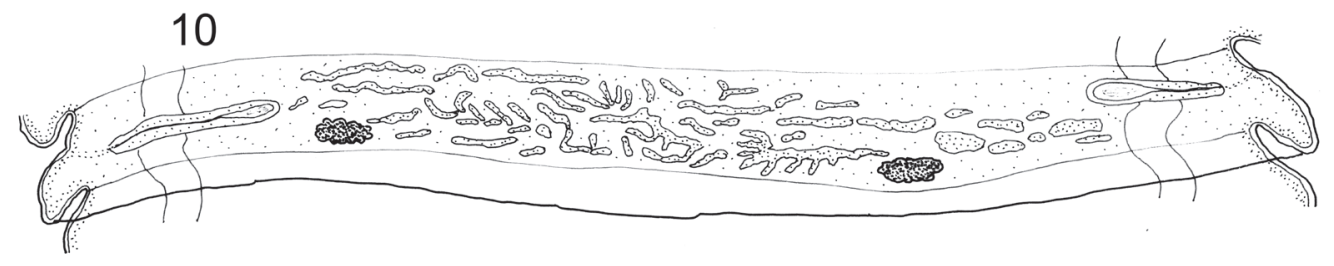

11
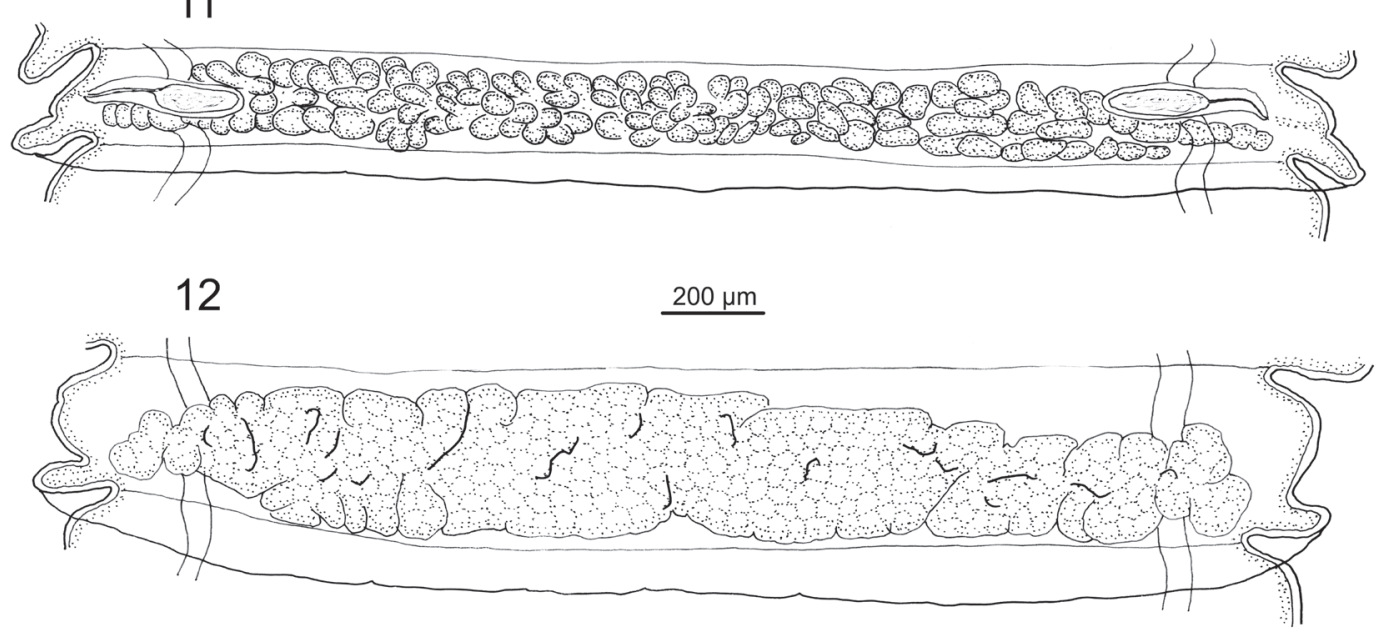

Figs. 10-12. Moniezia phacochoeri (Baylis, 1927) comb. n. Illustrations from specimens from South Africa. Fig. 10. Post-mature segment showing reticulate nature of early developing uterus. Fig. 11. Post-mature segment showing subsequent development of a lobulated uterus. Fig. 12. Gravid segment showing fully developed saccate uterus.

Mature segments laterally elongate, $250-340(290, \mathrm{n}=5)$ long, 3.3-4.5 (4.0, $\mathrm{n}=5) \mathrm{mm}$ wide; length: width ratio 11.5-16.7 (13.9, $\mathrm{n}=5)$; gravid segments 430-550 (500, $\mathrm{n}=5)$ long, 5.6-6.8 $(6.2, \mathrm{n}=5) \mathrm{mm}$ wide; length: width ratio $10.9-14.2(12.6, \mathrm{n}=5)$.

Genitalia paired; genital atrium deep, in mid-region of lateral margin of segment. Genital ducts cross osmoregulatory canals dorsally. Cirrus sac elongate, 580-730 (650, $\mathrm{n}=5)$ long, $140-160(150, \mathrm{n}=5)$ wide, with thick muscular wall, invariably extending to medial margin of ventral osmoregulatory canal or beyond into medulla. Distal cirrus thick-walled, unarmed; proximal cirrus with prominent spines (microtriches) in lumen; internal seminal vesicle 210-310 (260, $\mathrm{n}=5)$ long, 60-130 $(100, \mathrm{n}=5)$ wide; external seminal vesicle absent; vas deferens prominently coiled in whole mounts, with squamous glandular cells on outer surface in distal regions, becoming cuboidal and multi-layered in more proximal regions. Testes numerous, distributed throughout medulla except regions occupied by female genitalia; testes $50-80(60, \mathrm{n}=5)$ in diameter; number of testes per segment difficult to ascertain, distributed in 4-6 layers anteroposteriorly and 4-6 layers dorsoventrally; estimate of 150 per segment based on illustration.

Ovary flabelliform with numerous lobules, 420-720 $(620, \mathrm{n}=5)$ wide, $180-270(220, \mathrm{n}=5)$ long, situated close to osmoregulatory canals on ventral aspect of me- dulla. Vagina enters genital atrium posterior to cirrus sac; without sphincter; distal vagina surrounded by numerous layers of glandular cells externally, vaginal wall thick, muscular, armed with prominent basophilic microtriches internally; internal diameter 18-28 $(17, \mathrm{n}=5)$, external diameter $48-85(63, n=5)$. Vagina dorsal to cirrus sac on right hand side of segment, ventral to cirrus sac on left hand side of segment; in medulla, vagina curves ventrally medial to osmoregulatory canals, then loops back dorsally; convolution not evident in whole mounts; vagina terminates slightly medial to proximal pole of cirrus sac. Elongated duct without external investment of glandular cells leads from vagina to pyriform seminal receptacle, 140-250 (200, $\mathrm{n}=5)$ long, 90-130 (120, $\mathrm{n}=5)$ wide, either entirely lateral to vitellarium or at least lateral to centre of vitellarium.

Vitellarium faviform, mildly lobulated, 210-310 (240, $\mathrm{n}=5)$ wide, $80-110(90, \mathrm{n}=5)$ long, posterior and dorsal to ovary. Mehlis' gland seen only in transverse sections, dorsal to vitellarium. Uterus first visible as network of tubes spreading throughout segment; tubes enlarge to become lobules and gradually disappear. Fully developed uterus saccate; uterus extends beyond osmoregulatory canals dorsally.

Eggs (in water) quadrangular in shape, thick-shelled, 85-95 $(91, \mathrm{n}=5)$ in diameter; oncosphere 20-25 (22, $\mathrm{n}=$ $5)$ in diameter; pyriform apparatus with two elongate horns. 
Type host: Phacochoerus africanus (Gmelin).

Type locality: Zululand, South Africa.

Site of infection: small intestine.

Material examined: syntype specimens of $P$. phacochoeri, from $P h$. africanus (previously reported as $P h$. aethiopicus) from Zululand, South Africa: one slide with whole-mounted, immature specimen; seven slides with serial transverse sections; six slides with serial longitudinal sections (BMNH 1926.1.1.77-79); seven specimens from $P h$. africanus (previously reported as $P h$. aethiopicus), Hoedspruit, South Africa, 19 slides, whole mounts; seven slides with serial sections (BMNH 2013.6.20.1-3, OVRL S/2013/4.1-3).

Remarks. The specimens described here are the first gravid cestodes of this species reported and therefore the current description is the first full description of the species. In spite of the fact that Baylis' specimens (Baylis 1927) were immature and he therefore could not describe the uterus, the new specimens are readily identifiable as $P$. phacochoeri based on unique characters visible histologically. The vagina and proximal cirrus armed with prominent spine-like microtriches, the large muscular cirrus sac extending beyond the ventral osmoregulatory canal, the lack of a vaginal sphincter and particularly the prominent glandular investment of the vas deferens readily distinguish this species from the only other anoplocephalid cestode known from warthogs, M. mettami (see below).

The present description differs from that of Baylis (1927) in three features only, the number of testes, the position of the vagina in relationship to the cirrus sac and the presence or absence of a dorsal osmoregulatory canal. Baylis (1927) estimated that there were 60-80 testes per segment, compared with the estimate of 150 in this description. However, estimating the number of testes in these cestodes is extremely difficult as they occur in several dorsoventral layers. In the present study, an estimate was made by drawing all of the testes visible in one segment, by focusing up and down, and then counting the number of testes in the illustration. This method undoubtedly underestimates the number of testes as there will be a number overlooked. Baylis (1927) possibly made his estimate from the serial sections, which has inherent potential errors.

The second feature that differs between the two descriptions is the relative position of the vagina and cirrus sac. According to Baylis (1927), the vagina is ventral to the cirrus sac on the right side of the segment and dorsal or ventral on the left side, features which were confirmed in the type specimen. In the new sections made, the vagina is dorsal to the cirrus sac on the right side and ventral on the left. The significance of this difference is unclear, especially when all of the histological details match so precisely between the two lots of specimens. The apparent absence of the dorsal osmoregulatory canal in a small number of specimens is understandable. In spite of these minor differences, the material described here is considered to represent $P$. phacochoeri.

In the current specimens, the development of the uterus is clearly visible and it begins as a network of tubes, then becoming lobulated and finally becoming saccate. In P. suis, the uterus is tubular. For this reason, P. phacochoeri is transferred to the genus Moniezia as Moniezia phacochoeri (Baylis, 1927) comb. $\mathrm{n}$.

The specimens described here were reported earlier as either Moniezia or Paramoniezia based on an examination of the scoleces (Boomker et al. 1991). Other records of the species are those of Ortlepp (1964) from Zululand, Horak et al. (1983) from Namibia (again identified only as Moniezia or Paramoniezia), Jooste (1990) from Zimbabwe and Graber et al. (1980) from Ethiopia. The specimens from Zimbabwe were held in the helminthological collection of the Veterinary Research Laboratory, Harare, but are no longer extant while those from Ethiopia are housed in the Ecole National Vétérinaire, Lyon, France, but were not available for study.

Moniezia mettami Baylis, $1934 \quad$ Figs. 13-20, 22, 24

Redescription (based on specimens in MHNG). Largest mounted cestode (mature) $20.9 \mathrm{~cm}$ long, with numerous segments. Longitudinal musculature well developed, arranged in two layers; outer layer of small bundles of 2-10 fibres; inner layer of bundles much larger; transverse muscle fibres form narrow band immediately internal to longitudinal muscles; dorsoventral muscle fibres few, scattered.

Osmoregulatory canals paired; ventral canal larger, 80-240 $(130, n=5)$ in diameter, external to smaller dorsal canal, $10-30(20, n=5)$ in diameter; transverse canal connects ventral canals at posterior margin to each segment; no transverse dorsal canal seen.

Scolex 960-970 $(965, \mathrm{n}=2)$ in diameter, unarmed, with four suckers $250-260(255, \mathrm{n}=2)$ in diameter; neck 1030-2 $900(1970, n=2)$ long. Segments craspedote with narrow velum, $60-170(110, \mathrm{n}=5)$ overhanging small proportion of succeeding segment; mature segments 450-900 (640, $\mathrm{n}=5)$ long, 3450-5 $100(4030, \mathrm{n}=5)$ wide; length: width ratio $4.3-10.0(6.7, \mathrm{n}=5)$; gravid segments 450-1440 (1 070) long, 4450-9650 (7040) wide; length: width ratio $4.7-11.6(7.2, n=5)$.

Genitalia paired; genital pores shallow, in anterior region of lateral margin of segment. Genital ducts cross osmoregulatory canals dorsally. Cirrus sac pyriform, 210-240 (220, $\mathrm{n}=5)$ long, 70-110 (90, $\mathrm{n}=5)$ wide, thinwalled, either not reaching or just reaching external margin of ventral osmoregulatory canals. Cirrus thin-walled, unarmed. Internal seminal vesicle $60-90(70, n=5)$ long, 50-60 (56, $n=5)$ wide. External seminal vesicle absent. Vas deferens not prominent in whole mounts, without glandular cells on outer surface, coils medially near an- 

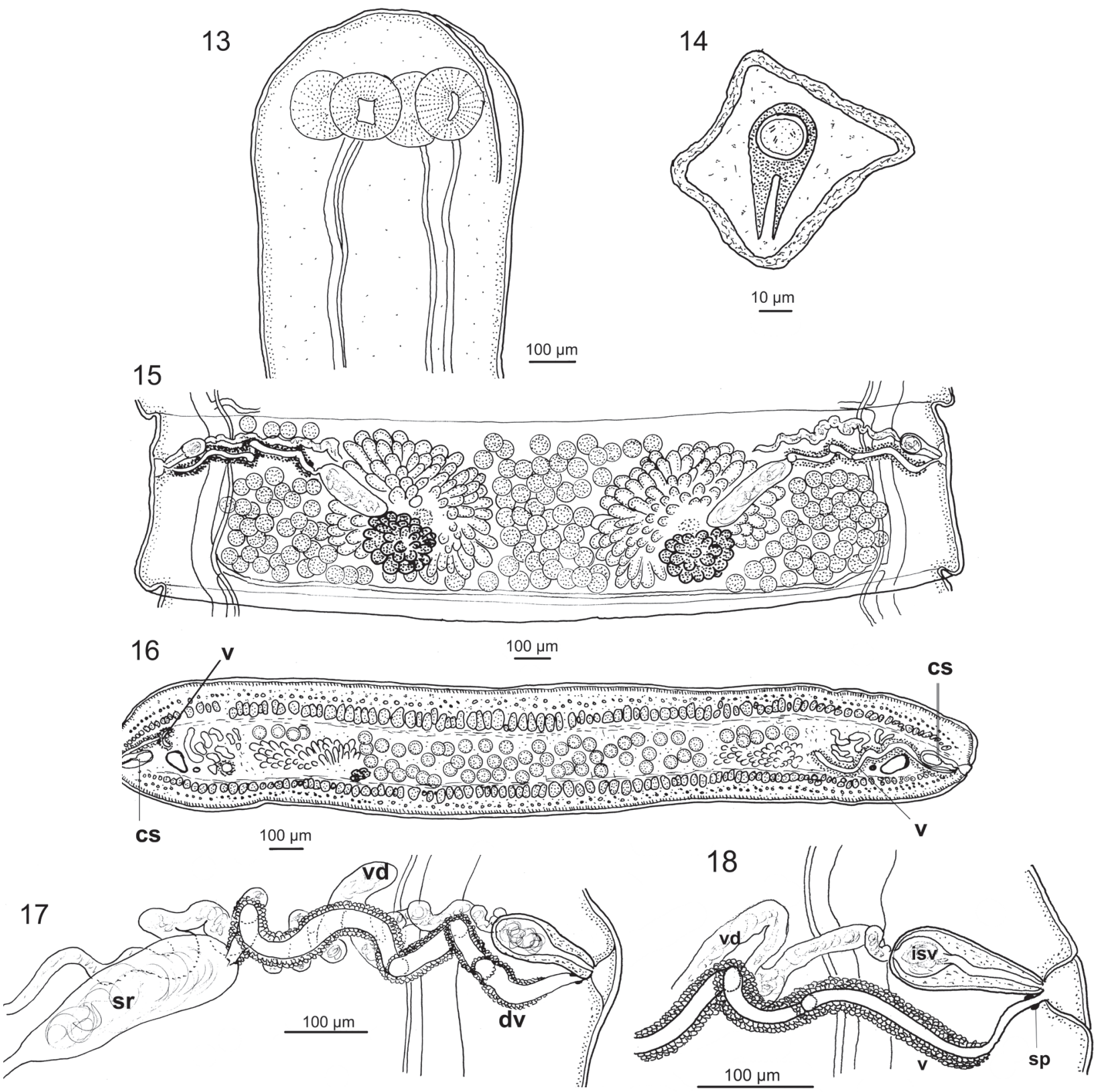

Figs. 13-18. Moniezia mettami Baylis, 1934. Illustrations from specimens in MHNG. Fig. 13. Scolex. Fig. 14. Egg. Fig. 15. Mature segment. Fig. 16. Transverse section of mature segment. Fig. 17. Terminal genitalia showing cirrus sac not reaching osmoregulatory canals and cellular investment of vagina. Fig. 18. Terminal genital ducts showing variation in position of cirrus sac in relation to osmoregulatory canals and vestigial sphincter in distal region of vagina. Abbreviations: cs - cirrus sac; dv - distal vagina; isv - internal seminal vesicle; $\mathrm{sp}$ - vaginal sphincter; $\mathrm{sr}$ - seminal receptacle; $\mathrm{v}$ - vagina; $\mathrm{vd}$ - vas deferens.

terior margin of medulla. Testes numerous, distributed throughout medulla except for areas occupied by female genitalia; testes 70-90 $(80, \mathrm{n}=5)$ in diameter; number of testes per segment difficult to ascertain, distributed in 4-8 layers anteroposteriorly and 3-4 layers dorsoventrally; number estimated from illustration about 160 .

Ovary flabelliform with numerous lobules, 230-800 long $(410, n=5), 450-850(600, n=5)$ wide, situated on ventral aspect of medulla. Vagina enters genital atrium posterior to cirrus sac; tiny sphincter present at entry into atrium; distal
80 of vagina without glandular investment; remainder of vagina surrounded by numerous layers of glandular cells externally, vaginal wall thick, muscular, not armed with prominent microtriches internally; internal diameter 30-90 (60, $\mathrm{n}=5)$, external diameter $70-110(80, \mathrm{n}=5)$. Vagina dorsal to cirrus sac on right hand side of segment, ventral to cirrus sac on left hand side of segment; vagina convoluted, longer than cirrus sac. Short duct without investment of glandular cells leads to pyriform seminal receptacle, 360-580 (420, $\mathrm{n}=5)$ long, 80-200 (86, $\mathrm{n}=5)$ wide. 

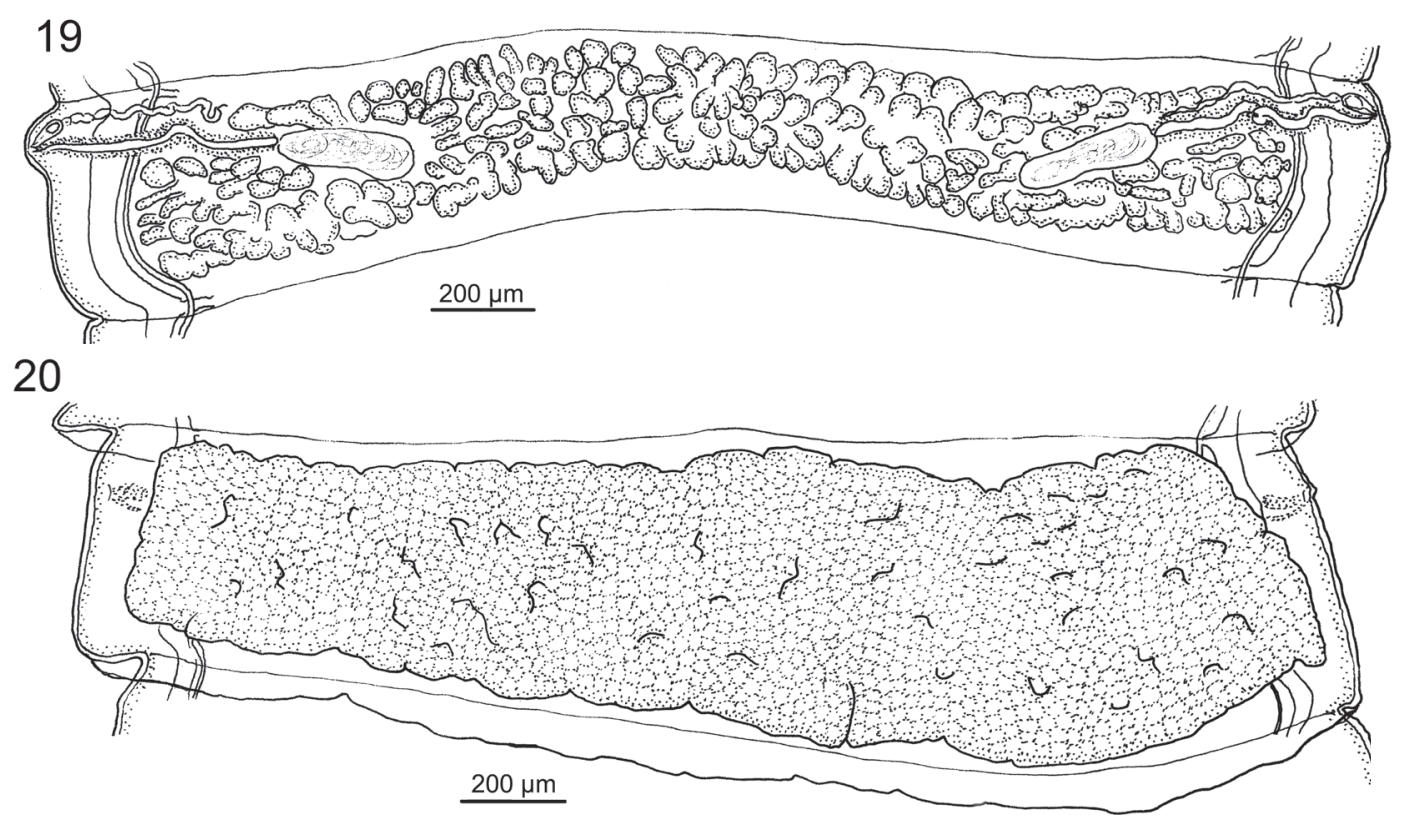

Figs. 19, 20. Moniezia mettami Baylis, 1934. Illustrations from specimens in MHNG. Fig. 19. Post-mature segment showing lobulated uterus. Fig. 20. Gravid segment showing saccate uterus.

Vitellarium faviform, mildly lobulated, 110-240 (170, $\mathrm{n}=5)$ long, $150-300(220, \mathrm{n}=5)$ wide, posterior and dorsal to ovary. Mehlis' gland visible only in sections, dorsal to vitellarium. Uterus first visible as network of tubes spreading throughout segment; tubes enlarge to become lobulate and gradually disappear; fully developed uterus saccate. Uterus extends just beyond osmoregulatory canals dorsally in fully gravid segments.

Eggs (mounted in unidentified medium) round in shape, thick-shelled, 130-170 $(140, \mathrm{n}=5)$ in diameter; oncosphere $10-50(26, \mathrm{n}=5)$ in diameter; pyriform apparatus consists of two elongate horns.

Type host: Phacochoerus africanus (Gmelin).

Type locality: Uganda.

Site in host: Small intestine.

Material examined: 'Syntypes' of M. mettami from $P h$. africanus (as Ph. aethiopicus), Uganda, three slides with whole mounts, 17 slides with transverse serial sections, 16 slides with serial longitudinal sections (BMNH 1934. 12.29.60-99); two specimens from $P h$. africanus (as Ph. aethiopicus), Gabu-Nioka, Congo, seven slides with whole mounts, 25 slides with serial sections (MHNG - PLAT 41595, 97/4-33, MHNG-PLAT 41596, 99/ 86-91).

Remarks. The present redescription is based upon the examination of the type specimens of M. mettami as well as specimens of M. mettami reported by Mahon (1954). The redescription was based on the latter specimens as they are in a better state of preservation. Baylis (1934) provided no illustrations of the species and Mahon (1954) provided only a brief redescription and a single figure and repeated Baylis' (1934) measurements. Hence the oppor- tunity has been taken here to redescribe and illustrate the species in full for the first time.

The redescription confirms the observations made by Baylis (1934) and Mahon (1954) in most details but differs in the number of testes per segment and the position of the vagina with respect to the cirrus sac. Baylis (1934) estimated that there were about 400 testes per segment, while the estimate made here by drawing as many testes as could be seen in a whole mount was 160 . The difficulties of estimating testis numbers have been discussed above and may be due to the use of different methods. In Mahon's (1954) material the vagina is dorsal to the cirrus sac on the right side and ventral on the left, the reverse of Baylis' (1934) description, although the significance of this difference is not clear given the otherwise close similarity between the specimens.

As indicated above, M. mettami is differentiable from M. phacochoeri on the basis of the size and armature of the cirrus sac (small and unarmed in M. mettami; robust and armed in the mid-region in M. phacochoeri), in the cirrus sac not reaching or just reaching the ventral canal in M. mettami while always reaching or extending beyond the canal in P. phacochoeri, in the morphology of the vas deferens as $M$. mettami lacks the glandular external investment seen in M. phacochoeri, and in the morphology of the vagina with a small sphincter present at its extremity in M. mettami, which is lacking in M. phacochoeri, and the lining of the vagina, which is smooth or corrugated in M. mettami but which is armed in M. phacochoeri. In addition, the vagina is relatively longer with respect to the cirrus sac in M. mettami compared with M. phacochoeri. 

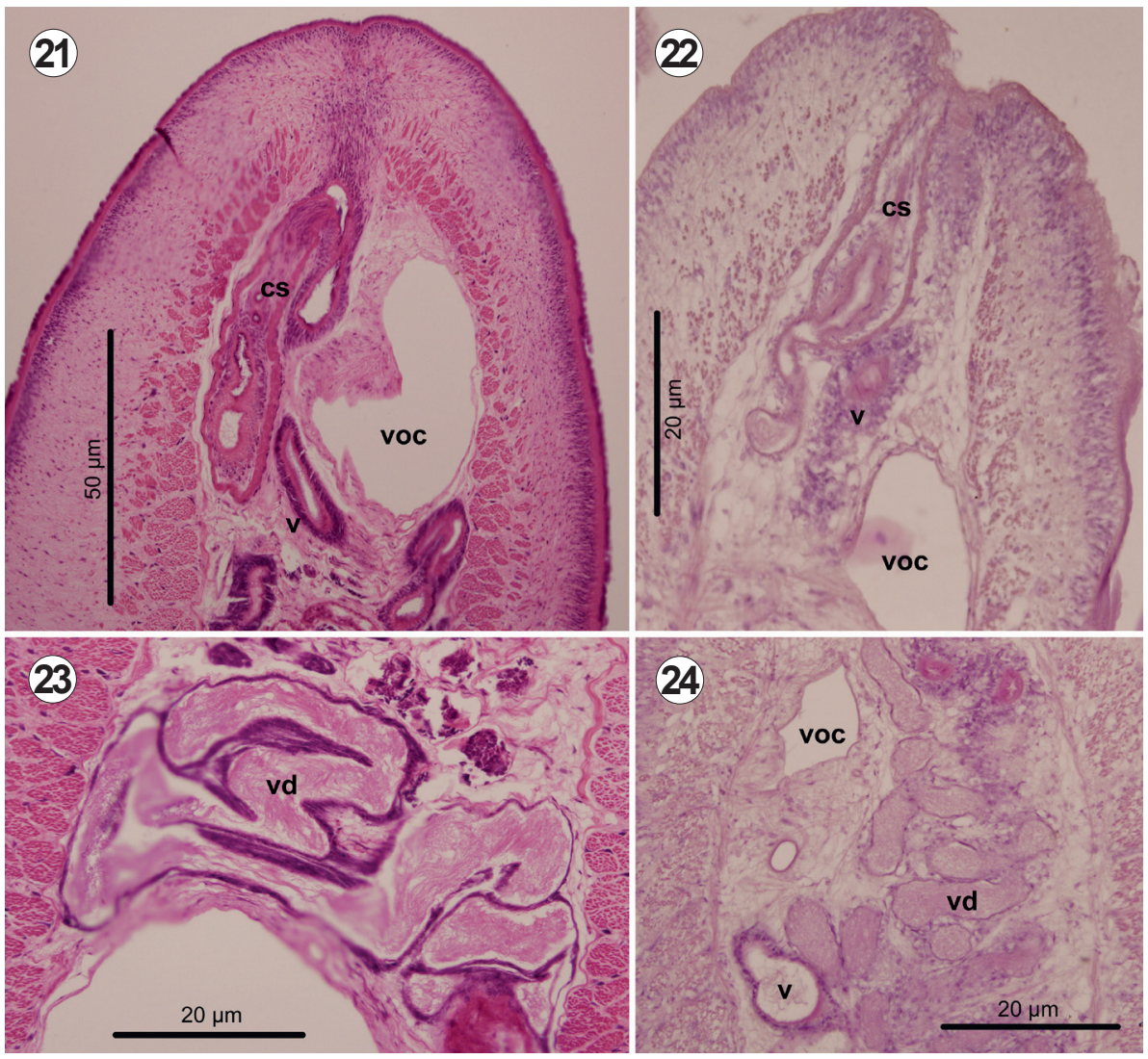

Figs. 21-24. Cirrus sacs and vasa deferentia of Moniezia phacochoeri (Baylis, 1927) and M. mettami Baylis, 1934. Fig. 21. Cirrus sac and distal vagina of M. phacochoeri showing extension of thick-walled cirrus sac to ventral osmoregulatory canal. Fig. 22. Cirrus sac and distal vagina of $M$. mettami showing thin-walled cirrus sac not reaching ventral osmoregulatory canal. Fig. 23. Vas deferens of M. phacochoeri showing investment of cells on outer surface. Fig. 24. Vas deferens of M. mettami showing lack of cellular investment on outer surface. Abbreviations: cs - cirrus sac; v - vagina; vd - vas deferens; voc - ventral osmoregulatory canal.

Additional records of this species include those of Mettrick (1962) from Zimbabwe, Ortlepp (1964) from Zululand, Troncy et al. (1972) from the Central African Republic and Graber et al. (1980) from Ethiopia. All previous reports have identified the host species as Ph. aethiopicus. However, more recently this taxon has been revised (Grubb 1993) and based on the geographical distributions of the host species, it appears that all previous reports referring to $P h$. aethiopicus currently refer to $P h$. africanus. The collection localities in Ethiopia reported by Graber et al. (1980) (Harrar, Awash) are within the geographical range of $P h$. africanus rather than that of $P h$. aethiopicus, based on host distributions provided by Grubb (1993).

\section{Phascolocestus gen. n.}

Definition: Large cestodes with numerous segments; scolex with four suckers, unarmed; segments craspedote; genitalia paired; genital ducts cross osmoregulatory canals dorsally. Cirrus sac elongate, extending beyond osmoregulatory canals; internal seminal vesicle present; testes distributed throughout medulla. Vagina opens to genital atrium posterior to cirrus sac; very large seminal receptacle present; ovaries poral; uterus single, transverse, tubular, developing anterior and posterior diverticula, extending beyond osmoregulatory canals in gravid segments. Pyriform apparatus present. Parasites of vombatid marsupials.

Ty pe species: Phascolocestus johnstoni (Beveridge, 1976) comb. n.; syn: Paramoniezia johnstoni Beveridge, 1976

Etymology: The new generic name is based on Phascolomys Duméril, an earlier generic name for wombats and now a synonym of Vombatus Geoffroy.

Phascolocestus johnstoni (Beveridge, 1976) comb. nov. Description: see Beveridge (1976)

Material examined: from Lasiorhinus krefftii (Owen): four specimens, Epping Forest National Park, Queensland, Australia (SAM 22863); from Lasiorhinus latifrons (Owen): two specimens, Sedan, South Australia (SAM 27695, 27721); 13 specimens, Swan Reach, South Australia (SAM 21507); from Vombatus ursinus (Shaw): one specimen, Sarsfield, Victoria (SAM 21503); two specimens, Steel's Creek, Victoria (SAM 23609, 23620); one specimen, Mt Wombat, Victoria (SAM 29293).

Remarks. A new genus has been erected for this species as it clearly does not belong to Paramoniezia as cur- 
rently understood. In Paramoniezia, as re-defined here, the cirrus sac is sub-globular and does not reach the osmoregulatory canals, and the distal vagina has a prominent glandular investment. In the new genus, the cirrus sac is elongate and extends to the osmoregulatory canals, while the distal vagina lacks a prominent glandular investment. Even if $P$. suis were to be in fact a specimen of Wallabicestus, based on the circumstantial evidence presented here, the molecular study of Hardman et al. (2012) clearly shows that this species from wombats represents a distinct genetic identity hence the need to erect a new genus.

Lasiorhinus krefftii is a new host record for P. johnsto$n i$. Although the only specimens available are extremely poorly preserved, all observable morphological features are identical with those of $P$. johnstoni. As the host is now extremely rare, with only about 115 surviving individuals (Horsup and Johnson 2008), it is unlikely that well-preserved material will become available in the near future.

New geographical records are provided for the occurrence of this cestode in L. latifrons and $V$. ursinus in Victoria and South Australia. The features used for the diagnosis of the new genus are those derived from the description of the species by Beveridge (1976).

\section{DISCUSSION}

The current review of the genus Paramoniezia has established that the type species, P. suis, purportedly collected from a wild pig in Queensland, Australia, is morphologically most similar to Wallabicestus ewersi, found commonly in wallabies in the same region of Australia and therefore implies that a labelling error has occurred in the description of this species and genus. However, the evidence presented to support this claim is in large part circumstantial and because of the very poor state of preservation of the type and only specimen and the fact that adult cestodes have never since been found in wild pigs in Australia (Mackerras 1958), there is insubstantial evidence to synonymise the two species. The speculation by Beveridge (1976) that $P$. suis might have been collected from the northern hairy-nosed wombat, Lasiorhinus $k r$ efftii, then occurring in the vicinity of Townsville, has now shown to be incorrect with cestodes from this extremely rare species of wombat being identified as $P$. johnstoni.

Given the new information presented here, the genus Paramoniezia has been retained as a genus inquirendum, with a single species, $P$. suis as a species inquirenda. All other species have been removed from the genus such that it no longer presents a complication in the current systematics of the Anoplocephalinae. It seems unlikely that any definitive decision can be reached on the identity of this species given the poor state of preservation of the type specimen and the fact that the taxon has never since been encountered in the host species recorded for the type specimen.
An additional species of Paramoniezia is P. phacochoeri from warthogs. Although described from immature specimens by Baylis (1927) without any details of the development of the uterus, the current redescription based on new material from South Africa clearly indicates that this species in fact belongs in Moniezia since it has a reticulated uterus in the early stages of uterine development, thus removing it from Paramoniezia. However, since there was an additional species of Moniezia, M. mettami, already described from the same host species, it was essential to establish whether M. mettami and M. phacochoeri were conspecific.

This proved not to be the case, with the two species being clearly distinct, based on a number of morphological characteristics considered in detail above, but with both distinguished from all congeners by the glandular investment of the vagina. Additional specimens are required to determine the geographical distributions of these two species in warthogs as the additional records have been based on incomplete descriptions of the two species (Mettrick 1962, Ortlepp 1964, Troncy et al. 1972, Graber et al. 1980).

The relationships of both M. mettami and M. phacochoeri with congeners remain to be determined. Within Moniezia, Spasskii (1951), following earlier Russian authors, split the genus into subgenera based on the presence and type of interproglottidal glands. Species without such glands were placed in the subgenus Baerezia Skrjabin et Schultz, 1937, including M. mettami, M. baeri Skrjabin, 1931 from reindeer, Rangifer tarandus Linnaeus, and M. rugosa (Diesing, 1850) from platyrhhine primates. Moniezia was identified as being in great need of revision by Beveridge (1978) and since then, it has been shown that both M. expansa (Rudolphi, 1810) and M. benedeni (Moniez, 1879) represent species complexes (Bâ et al. 1993, Chilton et al. 2007). In addition, Beveridge (1978) transferred $M$. rhea (Fuhrmann, 1904) from the ratite Rhea americana (Linnaeus) as well as M. becquarti (Viguerras, 1943) from the rodent Capromys pilorides Say, to the genus and in 1994 synonymised the genus Fuhrmannella Baer, 1925 with Moniezia, following the opinion of Baylis (1935).

Consequently, an additional species is $M$. transvaalensis (Baer, 1925) from the rodent Thryonomys swinderenianus Temminck. Given the current complexity of the genus Moniezia, it is beyond the scope of this study to differentiate $M$. phacochoeri and M. mettami from all of its congeners. However, within the current taxonomic arrangement proposed by Spasskii (1951), both are readily differentiated from M. rugosa by their large size and both are differentiated from M. baeri and all congeners by the massive glandular investment of the vagina.

Apart from P. phacochoeri, now removed to the genus Moniezia, the only remaining species within Paramoniezia is the wombat-inhabiting P. johnstoni. Since this 
species has a tubular rather than an initially reticulated uterus, it is more closely related to $P$. suis, and hence to $W$. ewersi, than to $P$. phacochoeri. However, molecular data (Hardman et al. 2012) as well as morphological information (Beveridge 1976) indicate that $P$. johnstoni represents a monophyletic taxon within the Anoplocephalinae and therefore warrants the erection of the new genus, Phascolocestus.

Using the key to the genera of the Anoplocephalinae of Beveridge (1994), the new genus is most similar to Ctenotaenia Railliet. 1893, parasitic in Eurasian Sciuridae (marmots), based on the presence of paired genitalia, a single, transverse uterus and testes distributed both anterior and posterior to the uterus. It differs from Ctenotaenia in that the testes extend poral to the ovaries in Phascolocestus but are restricted to the area between the ovaries in Ctenotaenia. It is differentiated from Phascolotaenia Beveridge, 1976, also from wombats, on the basis of testis distribution and the morphology of the seminal receptacle (Beveridge 1976).

A singular difficulty in the systematics of this group has been the erection of genera such as Paramoniezia based primarily on the relationships of the vagina and cirrus sac on each side of the segment with relatively little attention given to the extent of variation within this character. Variation is difficult to examine as it requires the examination of large numbers of serial transverse sections from multiple specimens. Serial sagittal sections are potentially useful but only if the left and right hand side are identifiable in advance, a situation which is difficult to achieve in practice. It may be that the relative positions of vagina and cirrus sac have been determined in few segments, but as the data presented here for $P$. suis indicate, the frequency of occurrence of variation may be limited so that if only one or two segments are examined, extrapolations may prove to be inaccurate. The position of the vagina with respect to the cirrus sac in transverse sections is a little used character in contemporary anoplocephaline systematics but warrants re-investigation even though the current data suggest that its value may be limited because of previously unexpected levels of variation.
One feature of significance in the current redescriptions was the difficulty of estimating the number of testes in each mature segment when several dorsoventral layers of testes were present. The methods by which testis numbers are estimated are either direct counts from drawings (as used here) or counts in what is assumed to be a single dorsoventral layer multiplied by the numbers of dorsoventral layers of testes observable in transverse sections. Both methods have significant limitations and as a consequence no great weight has been given here to disparities in testis number if hundreds of testes per segment are involved. It may be just as reliable to describe the testes as being 'numerous'.

The outcome of this review has been the identification of the genus Paramoniezia as a genus inquirendum based on the erroneous description of key differentiating features and possibly also based on an incorrect host identification. As the resolution of these difficulties is not possible, the proposal has been made to retain the genus as inquirendum with the type species as a species inquirenda. Of the remaining species previously accommodated in the genus, $P$. phacochoeri becomes a species of Moniezia based on the description of the uterus for the first time, but is distinct from M. mettami, found in the same host species, $P h$. africanus, but never formerly fully described. As a consequence, a new genus is needed for P. johnstoni from Australian wombats and hence Phascolocestus is proposed and defined to accommodate this species.

Acknowledgements. Sincere thanks are due to Dr. Kerstin Junker for providing specimens of $M$. phacochoeri from OVRL, Eileen Harris (BMNH) for help with access to type specimens, to Dr. Rodney A. Bray (BMNH) for taking photographs of type specimens of $P$. phacochoeri, and to Dr. Jean Mariaux (MHNG) for access to specimens in the collection of the Geneva museum. Thanks are also due to Dr. Roaland Jooste for advice on the status of collections in Zimbabwe and Dr. Lionel Zenner for advice on collections held in Lyon. Financial support for various aspects of this contribution was provided by the Australian Biological Resources Study, Australia and the National Science Foundation, USA (PBI 818823) through Dr. Janine N. Caira. Thanks are also due to two referees whose suggestions greatly improved the manuscript.

\section{REFERENCES}

Bâ T., Wang X.Q., Renaud F., Euzet L., Marchand B., De MeEÜs T. 1993: Diversity and specificity in cestodes of the genus Moniezia: genetic evidence. Int. J. Parasitol. 23: 853-857.

BAER J.G. 1927: Monographie de la famille des Anoplocephalidae. Bull. Biol. France Bèlge, Suppl. 10: 1-241.

Baylis H.A. 1927: On two adult cestodes from wild swine. Ann. Mag. Nat. Hist., ser. 9, 19: 417-425.

Baylis H.A. 1934: Notes on four cestodes. Ann. Mag. Nat. Hist., ser. 10, 14: 587-594.

Baylis H.A. 1935: Note on the cestode Moniezia (Fuhrmannella) transvaalensis (Baer, 1925). Ann. Mag. Nat. Hist., ser. 10, 15: 673-675.
Beveridge I. 1976: A taxonomic revision of the Anoplocephalidae (Cestoda: Cyclophyllidea) of Australian marsupials. Aust. J. Zool., Suppl. Ser. 44: 1-110.

Beveridge I. 1978: A taxonomic revision of the genera Cittotaenia Riehm, 1881, Ctenotaenia Railliet, 1893, Mosgovoyia Spasskii, 1951 and Pseudocittotaenia Tenora, 1976 (Cestoda: Anoplocephalidae). Mém. Mus. Hist. Nat., Paris, N. Sér. A, Zool. 10: $1-64$.

Beveridge I. 1994: Family Anoplocephalidae Cholodkovsky, 1902. In: L.F. Khalil, A. Jones and R.A. Bray (Eds.), Keys to the Cestode Parasites of Vertebrates. CAB International, Wallingford, pp. 315-366. 
BeVeridge I. 1998: Taxonomic revision of the genus Cloacina von Linstow (Nematoda: Strongyloidea) from macropodid marsupials. Invert. Taxon. 12: 273-508.

Beveridge I. 2009: A re-description of Progamotaenia ewersi (Schmidt, 1975) (Cestoda: Anoplocephalidae) from wallabies and kangaroos (Macropodidae), with the description of a new species, P. ualabati n. sp. Trans. R. Soc. S. Aust. 133: 1-17.

Boomker J., Horak I.G., Booyse D.G., Meyer S. 1991: Parasites of South African wildlife. VIII. Helminth and arthropod parasites of warthogs, Phacochoerus aethiopicus, in the eastern Transvaal. Onderst. J. Vet. Res. 58: 195-202.

Chilton N.B., O’Callaghan M.G., Beveridge I., Andrews R.H. 2007: Genetic markers to distinguish Moniezia expansa from M. benedeni (Cestoda: Anoplocephalidae) and evidence of the existence of cryptic species in Australia. Parasitol. Res. 100: 1187-1192.

Graber M., Blanc P., Delavenay R. 1980: Helminthes des animaux d'Ethiopie. I. Mammifères. Rev. Elev. Méd. Vét. Pays Tropic. 33: 143-158.

Grubb P. 1993: Wart hog. In: D. Wilson and D. Reeder (Eds.), Mammal Species of the World, Vol. 1, 2nd Edition. Smithsonian Institution Press, Washington and London, $377 \mathrm{pp}$.

Hardman L.M., Haukisalmi V., Beveridge I. 2012: Phylogenetic relationships of the anoplocephaline cestodes of Australasian marsupials and resurrection of the genus Wallabicestus Schmidt, 1975. Syst. Parasitol. 82: 49-63.

Horak I.G., Biggs H.C., Hanssen T.S., Hanssen R.E. 1983: The prevalence of helminth and arthropod parasites of warthog, Phacochoerus aethiopicus, in South West Africa/Namibia. Onderst. J. Vet. Res. 50: 145-148.

Horsup A., Johnson C.N. 2008: Northern hairy-nosed wombat Lasiorhinus krefftii (Owen, 1872). In: S. Van Dyck and R. Strahan (Eds.), The Mammals of Australia (3rd Edition). New Holland Publishers, Chatswood, Sydney, pp. 202-204.
Jooste R. 1990: A checklist of the helminth parasites of the larger domestic and wild mammals of Zimbabwe. Trans. Zimbabwe Sci. Assoc. 64: 15-32.

MackerRas J.M. 1958: Catalogue of Australian mammals and their recorded internal parasites. III. Introduced herbivora and the domestic pig. Proc. Linn. Soc. N. S. Wales 83: 143-153.

Mahon J. 1954: Contributions to the helminth fauna of tropical Africa. Tapeworms from the Belgian Congo. Annal. Mus. Roy. Congo Belge, Zool., Sér V, 1: 1-261.

Maplestone P.A., Southwell T. 1923: Notes on Australian cestodes. Ann. Trop. Med. Parasitol. 17: 317-331.

Mettrick D.F. 1962: Some trematodes and cestodes from mammals of central Africa. Rev. Biol. 3: 149-170.

OrtLePp R.J. 1964: Observations on the helminths parasitic in warthogs and bushpigs. Onderst. J. Vet. Res. 31: 11-38.

SCHмIDT G.D. 1986: CRC Handbook of Tapeworm Identification. CRC Press, Boca Raton, Florida, 675 pp.

Spasski A.A. 1951: Essentials of Cestodology I. Anoplocephalate Tapeworms of Domestic and Wild Animals. Ed. K.I. Skrjabin. Akademia Nauk CCCP: Moskva. English translation by The Israel Program for Scientific Translations, Jerusalem, 1963, $783 \mathrm{pp}$.

Speare R., Beveridge I., Johnson P.M., Corner L.A. 1983: Parasites of the agile wallaby, Macropus agilis (Marsupialia). Aust. Wildl. Res. 10: 89-96.

Troncy P.M., Graber M, Thal J. 1972: Enquête sur la pathologie de la faune sauvage en Afrique centrale. Le parasitisme des Suidés sauvages. Premiers résultats d'enquête. Rev. Ele. Méd. Vét. Pays Trop. 25: 205-218.

Yamaguti S. 1959: Systema Helminthum. II. The Cestodes of Vertebrates. Interscience Publishers, New York, 860 pp.

Yorke W., Maplestone P.A. 1926: The Nematode Parasites of Vertebrates. J. \& A. Churchill, London, 536 pp. 